\title{
Association of TAP1 Gene Polymorphism in Human Papilloma Virus Related Oropharyngeal Cancer
}

\author{
Sindhura Suryanarayana ${ }^{1,2}$, Jaimanti Bakshi1 ${ }^{*}$, Malay Sannigrahi3 ${ }^{3}$ Rajni Sharma ${ }^{3}$, \\ Naresh K. Panda1, Madhu Khullar ${ }^{3 *}$ \\ ${ }^{1}$ Department of Otolaryngology \& Head Neck Surgery, Postgraduate Institute of Medical Education \& Research, \\ Chandigarh, India \\ ${ }^{2}$ Department of Otolaryngology \& Head Neck Surgery, Sri Devaraj Urs Medical College, Kolar, India \\ ${ }^{3}$ Department of Experimental Medicine and Biotechnology, Postgraduate Institute of Medical Education \& Research, \\ Chandigarh, India \\ Email: ${ }^{\star}$ sindhuramanjunath@gmail.com
}

How to cite this paper: Suryanarayana, S., Bakshi, J., Sannigrahi, M., Sharma, R., Panda, N.K. and Khullar, M. (2020) Association of TAP1 Gene Polymorphism in Human Papilloma Virus Related Oropharyngeal Cancer. Surgical Science, 11, 1-8. https://doi.org/10.4236/ss.2020.111001

Received: August 9, 2019

Accepted: January 7, 2020

Published: January 10, 2020

Copyright $\odot 2020$ by author(s) and Scientific Research Publishing Inc. This work is licensed under the Creative Commons Attribution International License (CC BY 4.0).

http://creativecommons.org/licenses/by/4.0/

\begin{abstract}
Background: Polymorphisms of TAP1 gene might be pertinent in development of cancer by altering the immune response. We studied the association of TAP1 gene polymorphism with HPV related oropharyngeal cancer. Methods: This prospective study consisted of 200 subjects divided into three groups; Group A-HPV positive oropharyngeal cancer (17/100), Group B-HPV negative oropharyngeal cancer (83/100) and Group C-Controls. TAP1ile333val polymorphism genotyping was performed by ARMS-PCR. Results: No significant difference was observed in the distribution of $\mathrm{Val} / \mathrm{Val}$ genotype of Group A in comparison to Group C $(\mathrm{OR}=0.663,95 \% \mathrm{CI}=0.164-2.688, p$ $=0.742)$ and Group B $(\mathrm{OR}=1.725,95 \% \mathrm{CI}=0.388-7.675, p=0.677)$ and thus was not associated with HPV associated cancer. But the frequency of $\mathrm{Val} / \mathrm{Val}$ genotype was found to be significantly decreased in Group B as compared to controls and was linked with increased risk of oropharyngeal cancers $(\mathrm{OR}=0.38,95 \% \mathrm{CI}=0.15-0.97, p=0.048)$. Conclusion: TAP1i333v gene polymorphism was not associated with HPV positive oropharyngeal cancer; however decreased frequency of $\mathrm{Val} / \mathrm{Val}$ genotype raises the risk of oropharyngeal cancer.
\end{abstract}

\section{Keywords}

TAP1, HPV, Oropharyngeal Cancer, HNSCC, ARMS-PCR 


\section{Introduction}

Head and Neck Squamous Cell Carcinoma (HNSCC) is the sixth most common cancer with approximately 6 million cases being reported annually all over the world and oropharyngeal squamous cell carcinoma accounts for approximately 10\% [1] of all HNSCC. An association between HNSCC and human papillomavirus (HPV) was postulated more than twenty years ago [2]. A wide variation in the prevalence of HPV is seen all through the upper aerodigestive tract tumors, among which a stronger link of these oncogenic viruses appears with those cancers arising from oropharynx. It has been demonstrated that HPV related oropharyngeal cancers present with a specific molecular, clinical and pathologic patterns that are possibly associated with HPV infection [3]. Also they are less likely associated with traditional risk factors such as alcoholism and smoking [4]. Several studies identify a survival advantage [5] [6] despite advanced disease.

It has been observed that all the individuals infected with HPV are not able to eradicate this oncogenic virus. Thus suggesting that host genetic backgrounds may account, at least partly, for the development of HPV associated oropharyngeal cancer. Defect in the cell-mediated immune response may be one of the possible mechanisms which contribute to this altered ability to eradicate HPV. Major Histocompatibility Complex (MHC) class I molecules exhibit a critical role in immune recognition of virus-infected cells. The Transporter associated with Antigen Processing (TAP) is a vital component of MHC class I antigen presentation [7]. TAP products facilitate the entry of viral proteins into the rough endoplasmic reticulum which further integrates with MHC-I molecules [8]. Earlier studies have provided evidence for the role of genetic polymorphisms of TAP1 gene in modulating immune response to HPV and hence their persistence leading to increased risk of tumorigenesis [9]. Thus, genetic polymorphisms of TAP1 gene may therefore enhance the tumorigenesis by hampering TAP functions and giving a survival advantage to HPV. Given the role of deficiencies in TAP1 gene with immune recognition of HPV and related tumorigenesis, the variant TAP proteins are potential candidates for predisposition to HPV related oropharyngeal cancer. However, data regarding the association of TAP1 gene polymorphisms with risk of HPV related oropharyngeal cancer is lacking. Several previous association analyses in HPV positive cervical cancers have provided conflicting results [10] [11]. So our present work aimed to study the association of TAP1 gene polymorphisms with susceptibility to HPV related oropharyngeal cancer.

\section{Material and Methods}

\subsection{Subjects}

100 cases of biopsy proven oropharyngeal cancers (for Squamous cell carcinoma) presenting to the Department of Otolaryngology and Head Neck Surgery of Post Graduate Institute of Medical Education and Research (PGIMER), Chan- 
digarh, India were included in this study. The research protocol was approved by the Institute Research Ethics Committee, PGIMER. The study period was from July 2011 to December 2012. All patients were screened for HPV status and then grouped as A and B depending on their HPV status. Group A and B comprised of HPV positive and HPV negative oropharyngeal cancer patients respectively. Group C consisted of 100 healthy subjects who had no clinical manifestations of HPV infection/chronic illness nor had any family history of cancer. Informed consent was obtained from all cases and controls.

\subsection{Genotyping}

Genomic DNA was isolated from peripheral blood lymphocytes using proteinase $\mathrm{K}$ digestion and phenol chloroform method [12]. Tumor samples were screened for HPV16 DNA using a HPV16-specific PCR for E6 (Forward primer A,

5'-TCAAAAGCCACTGTGTCCTGA-3' and primer B,

5'-CGTGTTCTTGATGATCTGCAA-3'). $\beta$-globulin was used as an internal control. HPV 16 primers were standardized with pool DNA of positive control from temperature $48^{\circ} \mathrm{C}$ to $57^{\circ} \mathrm{C}$ (gradient: $48,48.6,49.7,51.3,53.4,55.2,56.3,57.0$ ), $2.5 \mathrm{mM} \mathrm{MgCl}_{2}$ and product size of $119 \mathrm{bp}$. TAP1I333V polymorphism genotyping was performed by amplification refractory mutation system-polymerase chain reaction (ARMS-PCR) (Figure 1) as described by Powis et al. [13]. Briefly, in this method, four primers were used for the dimorphic site at 333. Two of these were complementary to one of the dimorphic sites, while the other two allele-nonspecific primers were used as an internal control. PCR conditions were standardized for these two sets of primers and genomic DNA was amplified using optimized conditions as mentioned.

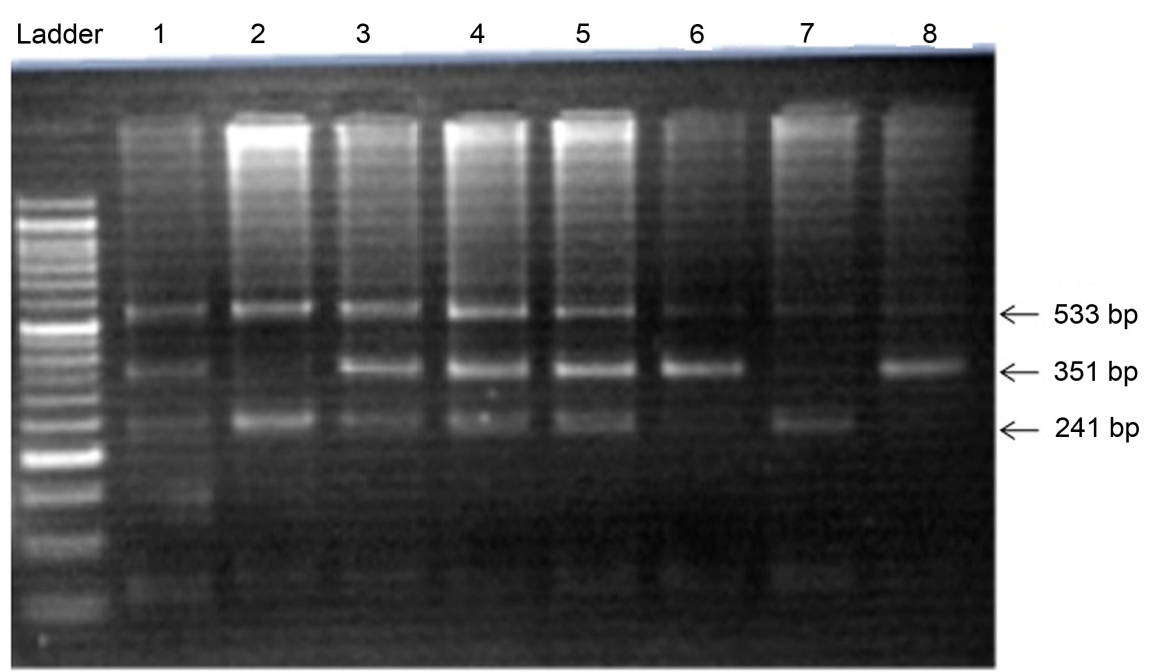

Figure 1. Representative PCR products for TAP1gene i333v polymorphism analysed on $2 \%$ agarose gel. Lane 2 \& 7: control \& allele specific 241 bp and 533 bp fragments defining the Ile/Ile homozygote. Lane 1, 3, 4-5: control and allele specific, smaller fragments (241 bp, $351 \mathrm{bp}$ and $533 \mathrm{bp}$ ) defining Ile/Val heterozygote. Lane 6 \& 8: control and allele specific $351 \mathrm{bp}$ and $533 \mathrm{bp}$ fragments defining the Val/Val homozygote. 
Details of the primers:

Codon Sequence (5' to 3') Specificity Size (bp)

TAP1333CCCTGCACTGAGATTTGCAGACCTCTGGAG5’ flanking Control; 533

GATCAGTGTCCCTCACCATGGTCACCCGGA Ile-333 Ile-333; 241

GGGCAGAAGGAAAAGCAGAGGCAGGGTCAC Val-333 Val-333; 351

ACCTGGGAACATGGACCACAGGGACAGGGT 3' flanking

PCR was setup under sterile conditions. The PCR reaction mixture $(25 \mu \mathrm{l})$ contained $1 \mu$ l of DNA, $0.25 \mathrm{mM}$ of dNTP, 10 pmol of each primers, 10X PCR buffer, $2.5 \mathrm{mM} \mathrm{MgCl}_{2}$, and 1 unit of thermostable Taq DNA polymerase. The PCR reaction composition has been listed in Table 1 .

The PCR tubes were given a brief spin to mix the contents and then placed in the thermal cycler. The gradient PCR of TAP 1 from $58^{\circ} \mathrm{C}$ to $65^{\circ} \mathrm{C}$ at a concentration of $1.5 \mathrm{mM} \mathrm{MgCl}_{2}$ and $2.5 \mathrm{mM} \mathrm{MgCl}_{2}$ were studied. PCR was carried out at $95^{\circ} \mathrm{C}$ for $5 \mathrm{~min}$ (Initial denaturation), 35 cycles of $1 \mathrm{~min}$ at $95^{\circ} \mathrm{C}$ (denaturation), $45 \mathrm{~s}$ at $62^{\circ} \mathrm{C}$ (annealing), $72^{\circ} \mathrm{C}$ for $1 \mathrm{~min}$ (extension) followed by a final extension of $10 \mathrm{~min}$ at $72^{\circ} \mathrm{C}$.

DNA isolated was checked for integrity on $2 \%$ agarose gel stained by ethidium bromide, by electrophoresis and picture of gel was taken on GelDoc (BioRad). Genotyping results were interpreted as follows: Ile/Val if 241, 351 and $533 \mathrm{bp}$ bands were visible, Ile/Ile if 241 and 533 bp bands were visible, and Val/Val if 351 and 533 bp bands were visible.

\section{Statistical Analysis}

Statistical analysis was performed using the SPSS software (version 16.0). Hardy Weinberg equilibrium (HWE) calculator was used to check deviation from HWE. The risk to HPV positive oropharyngeal cancer in relation to polymorphic prevalence was evaluated using Pearson's $\chi^{2}$ test to calculate odds ratio and $95 \%$ confidence intervals after adjustment for potential confounders. Wild type genotype was used as reference category in the statistical analysis. A two sided $p$ value of $<0.05$ was considered statistically significant.

Table 1. Reaction composition used TAP1I333V polymorphism.

\begin{tabular}{cc}
\hline Components & Volume \\
\hline Taq Buffer $(10 \mathrm{X})$ & $2 \mu \mathrm{l}$ \\
$\operatorname{MgCl}_{2}(25 \mathrm{mM})$ & $2.5 \mu \mathrm{l}$ \\
$\operatorname{dNTPs}(25 \mathrm{mM})$ & $0.25 \mu \mathrm{l}$ \\
Forward Primer $(10 \mu \mathrm{M})$ & $1 \mu \mathrm{l}$ \\
Reverse Primer $(10 \mu \mathrm{M})$ & $1 \mu \mathrm{l}$ \\
DNA & $1 \mu \mathrm{l}$ \\
Taq Polymerase $(1 \mathrm{unit} / \mu \mathrm{l})$ & $1 \mu \mathrm{l}$ \\
Water & $16.25 \mu \mathrm{l}$ \\
Total & $25 \mathrm{ml}$ \\
\hline
\end{tabular}




\section{Results}

Demographic profile of patients and control subjects is given in Table 2. $17 \%$ patients were found to be HPV 16 positive. Thus Group A had 17 cases of HPV positive oropharyngeal cancer and Group B consisted of 83 cases of HPV negative oropharyngeal cancer. The genotype and allele frequency of patients and controls are given in Table 3 and Table 4. Allele frequency of TAP1I333V gene polymorphism was consistent with Hardy Weinberg Equilibrium (HWE).

No significant difference in distribution of Val/Val genotype in Group A was observed when compared to Group $\mathrm{C}(\mathrm{OR}=0.663,95 \% \mathrm{CI}=0.164-2.688, p=$ $0.742)$ and Group B (OR $=1.725,95 \% \mathrm{CI}=0.388-7.675, p=0.677)$. However, the frequency of $\mathrm{Val} / \mathrm{Val}$ genotype was found to be significantly decreased in the Group B as compared to controls and this decrease was associated with increased risk of oropharyngeal cancers $(\mathrm{OR}=0.38,95 \% \mathrm{CI}=0.15-0.97, p=0.048)$. No significant difference in distribution of $\mathrm{Val}$ allele among Group $\mathrm{A}$ as compared to controls $(\mathrm{OR}=0.665,95 \% \mathrm{CI}=0.302-1.468, p=0.343)$. Whereas the prevalence of Val allele was significantly decreased in the Group B when compared to controls and this decrease was associated with increased risk of oropharyngeal cancers $(\mathrm{OR}=0.59,95 \% \mathrm{CI}=0.38-0.98, p=0.025)$ (Table 3$)$. The frequency of $\mathrm{Val}$ allele was significantly higher in controls than in cases $(\mathrm{OR}=0.606,95 \% \mathrm{CI}=0.397$ - 0.923, $p=0.025$ ) and was associated with decreased risk of cancer in controls.

Table 2. Demographic profile of study population.

\begin{tabular}{|c|c|c|c|c|c|c|c|c|}
\hline Characteristics & $\begin{array}{l}\text { Group A } \\
(\mathrm{n}=17)\end{array}$ & $\begin{array}{l}\text { Group B } \\
(\mathrm{n}=83)\end{array}$ & $\begin{array}{l}\text { Group C } \\
(n=100)\end{array}$ & $\begin{array}{l}\text { Group A+ } \\
B(n=100)\end{array}$ & $\begin{array}{c}\text { A vs } \\
\text { B }\end{array}$ & $\begin{array}{c}\text { A vs } \\
\mathrm{C} \\
p \mathrm{v}\end{array}$ & $\begin{array}{c}\text { B vs } \\
\text { C }\end{array}$ & $\begin{array}{c}A+B \\
\text { vs C }\end{array}$ \\
\hline Mean Age (yrs) & $\begin{array}{c}51.94 \pm \\
9.46\end{array}$ & $\begin{array}{c}54.19 \pm \\
12.41\end{array}$ & $\begin{array}{c}48.9 \pm \\
13.62\end{array}$ & $\begin{array}{c}51.36 \pm \\
13.01\end{array}$ & 0.482 & 0.379 & 0.007 & 0.007 \\
\hline Gender & & & & & & & & \\
\hline Males & $15(88.2)$ & $75(90.40)$ & $71(71)$ & $10(10)$ & 0.709 & 0.137 & 0.001 & 0.001 \\
\hline Females & $2(11.8)$ & $8(9.60)$ & $29(29)$ & $90(90)$ & & & & \\
\hline Smokers & $14(82.4)$ & $62(74.7)$ & $30(30)$ & $76(76)$ & 0.501 & 0.001 & 0.001 & 0.001 \\
\hline Non smokers & $3(17.6)$ & $21(25.3)$ & $70(70)$ & $24(24)$ & & & & \\
\hline Pack years (Yrs) & $\begin{array}{c}17.58 \pm \\
11.77\end{array}$ & $\begin{array}{c}14.57 \pm \\
11.76\end{array}$ & $\begin{array}{c}10.42 \pm \\
10.41\end{array}$ & $\begin{array}{c}13.80 \pm \\
11.53\end{array}$ & 0.267 & 0.048 & 0.103 & 0.058 \\
\hline Alcoholics & $7(41.20)$ & $44(53)$ & $22(22)$ & $51(51)$ & 0.791 & 0.09 & 0.001 & 0.001 \\
\hline Non alcoholics & $10(58.80)$ & $39(37)$ & $78(78)$ & $49(49)$ & & & & \\
\hline Tobacco chewing & $4(23.5)$ & $20(24.1)$ & $16(16)$ & $24(24)$ & 0.96 & 0.367 & 0.367 & 0.157 \\
\hline Non tobacco chewing & $13(76.5)$ & $63(75.9)$ & $84(84)$ & $76(76)$ & & & & \\
\hline $\begin{array}{l}\text { Concurrent } \\
\text { consumption of } \\
\text { tobacco and alcohol }\end{array}$ & $6(35.3)$ & $36(43.37)$ & $12(12)$ & $42(42)$ & 0.900 & 0.011 & 0.013 & 0.012 \\
\hline
\end{tabular}

Age analyzed by t test; rest by Pearsons Chi square test. 
Table 3. TAP1 genotypes among various groups.

\begin{tabular}{cccccc}
\hline $\begin{array}{c}\text { Polymorphism } \\
\text { TAP1 333 }\end{array}$ & $\begin{array}{c}\text { Group C } \\
\mathbf{n}(\%)\end{array}$ & $\begin{array}{c}\text { Group A } \\
\mathbf{n}(\%)\end{array}$ & $\begin{array}{c}\text { Group B } \\
\mathbf{n}(\%)\end{array}$ & $\begin{array}{c}\text { Group A + B } \\
\mathbf{n}(\%)\end{array}$ & $\begin{array}{c}\text { OR (95\% CI); } p \\
\text { A vs B }\end{array}$ \\
\hline Ile/Ile & $42(42.00)$ & $10(58.82)$ & $46(55.42)$ & $56(56.00)$ \\
Ile/Val & $39(39.00)$ & $4(23.53)$ & $29(34.94)$ & $33(33.00))$ \\
OR (95\% CI); $p^{*}$ & & $0.43(0.125-1.486) ;$ & $0.679(0.359-1.284) ;$ & $0.635(0.344-1.171) ;$ & $0.634(0.182-2.212) ;$ \\
Val/Val & $19(19.00)$ & 0.246 & 0.26 & 0.163 & 0.558 \\
OR (95\% CI); $p^{*}$ & & $0.663(0.164-2.688)$ & $0.38(0.15-0.97) ;$ & $0.43(0.187-1.009) ;$ & $1.725(0.388-7.675) ;$ \\
\end{tabular}

*-Pearsons chi squared test.

Table 4. TAP1 alleles among various groups.

\begin{tabular}{cccccc}
\hline $\begin{array}{c}\text { Polymorphism } \\
\text { TAP1 333 }\end{array}$ & $\begin{array}{c}\text { Group C } \\
\text { n (\%) }\end{array}$ & $\begin{array}{c}\text { Group A } \\
\text { n (\%) }\end{array}$ & $\begin{array}{c}\text { Group B } \\
\text { n (\%) }\end{array}$ & $\begin{array}{c}\text { Group A + B } \\
\text { n (\%) }\end{array}$ & $\begin{array}{c}\text { OR (95\% CI); } p^{*} \\
\text { A vs B }\end{array}$ \\
\hline Ile & $123(61.50)$ & $24(70.58)$ & $121(72.89)$ & $145(72.50)$ \\
Val & $77(38.50)$ & $10(29.41)$ & $45(27.11)$ & $55(27.50)$ & \\
OR (95\% CI); $p^{*}$ & & $0.665(0.302-1.468) ;$ & $0.59(0.38-0.98) ;$ & $0.606(0.397-0.923) ;$ & $1.120(0.497-2.527) ;$ \\
& & 0.343 & 0.025 & 0.025 & 0.834 \\
\hline
\end{tabular}

*-Pearsons chi squared test.

\section{Discussion}

Pathogenic mechanism of HPV related oropharyngeal cancers is one of the controversial issues and thus the association between HPV related oropharyngeal cancers and genetic polymorphism is of growing interest. The current work attempted to identify the possible relation between TAP1 gene polymorphism and the risk of developing oropharyngeal cancers. Our data showed lack of association between risk of HPV positive oropharyngeal cancer and TAP1I333V gene polymorphism. However, lower frequency of Val/Val genotype and Val allele appears to increase the risk of oropharyngeal cancer. Thus individuals within control group who were carriers of increased frequency of Val/Val genotype were protected from oropharyngeal cancer. These results are in concordance to earlier reports which showed that TAP1I333V polymorphisms were associated with a protective effect for development of cervical cancer [14] [15]. TAP gene polymorphisms have been shown to influence susceptibility to various diseases including tumorigenesis by modulating antigen peptide selection and transport process [16] [17]. Einstein et al. [18], observed that TAP1 i333v products protect against immune evasion regardless of the oncogenicity of HPV type in cervical neoplasia.

TAP is a vital component of MHC class I antigen presentation [7] and TAP products facilitate the entry of viral proteins into the rough endoplasmic reticulum which further integrates with MHC-I molecules [8]. Thus, dysregulation of TAP gene may modulate immune response to HPV and hence their persistence. 
Liu et al. have shown that loss of expression of MHC class I and TAP1 results in evasion of immune surveillance by some tumor cells which may contribute to esophageal cancers [19]. Our study further supports that TAP1 i333v polymorphisms may potentially serve to identify people susceptible to oropharyngeal cancer.

However, our study has several limitations, foremost being limited sample size. Secondly, all clustered polymorphism sites of TAP1 and associated genes were not included and the haplotypes analysis could not be performed, which has been shown to be a better predictor of susceptibility in cervical cancer [20].

In conclusion our results show that lower frequency of Val/Val genotype of TAP1i333v gene polymorphism may be associated with increased risk of oropharyngeal cancer. However, further studies with larger population along with all clustered polymorphism sites of TAP1 and associated genes are needed to confirm these results.

\section{Conflicts of Interest}

The authors declare no conflicts of interest regarding the publication of this paper.

\section{References}

[1] Parkin, D.M., Bray, F., Ferlay, J. and Pisani, P. (2005) Global Cancer Statistics, 2002. CA: A Cancer Journal for Clinicians, 55, 74-108. https://doi.org/10.3322/canjclin.55.2.74

[2] Kreimer, A.R., Clifford, G.M., Boyle, P. and Franceschi, S. (2005) Human Papillomavirus Types in Head and Neck Squamous Cell Carcinomas Worldwide: A Systematic Review. Cancer Epidemiology, Biomarkers \& Prevention, 14, 467-475. https://doi.org/10.1158/1055-9965.EPI-04-0551

[3] Klussmann, J.P., Weissenborn, S.J., Wieland, U., et al. (2003) Human Papillomavirus-Positive Tonsillar Carcinomas: A Different Tumor Entity? Medical Microbiology and Immunology, 192, 129-132. https://doi.org/10.1007/s00430-002-0126-1

[4] Lindel, K., Beer, K.T., Laissue, J., Greiner, R.H. and Aebersold, D.M. (2001) Human Papillomavirus Positive Squamous Cell Carcinoma of the Oropharynx: A Radiosensitive Subgroup of Head and Neck Carcinoma. Cancer, 92, 805-813. https://doi.org/10.1002/1097-0142(20010815)92:4<805::AID-CNCR1386>3.0.CO;2-9

[5] Wittekindt, C., Gultekin, E., Weissenborn, S.J., et al. (2005) Expression of p16 Protein Is Associated with Human Papillomavirus Status in Tonsillar Carcinomas and Its Implications on Survival. Advances in Oto-Rhino-Laryngology, 62, 72-80. https://doi.org/10.1159/000082474

[6] Abele, R. and Tampe, R. (1999) Function of the Transport Complex TAP in Cellular Immune Recognition. Biochimica et Biophysica Acta, 1461, 405-419. https://doi.org/10.1016/S0005-2736(99)00171-6

[7] Engelhard, V.H. (1994) How Cells Process Antigens. Scientific American, 271, 54-61. https://doi.org/10.1038/scientificamerican0894-54

[8] Seliger, B., Maeurer, M.J. and Ferrone, S. (2000) Antigen-Processing Machinery Breakdown and Tumor Growth. Trends in Immunology, 9, 455-464.

https://doi.org/10.1016/S0167-5699(00)01692-3 
[9] Seliger, B., Maeurer, M.J. and Ferrone, S. (1997) TAP off-Tumors on. Trends in Immunology, 18, 292-299. https://doi.org/10.1016/S0167-5699(97)80026-6

[10] Tamandani, D.M.K., Sobti, R.C., Shekari, M., Ali Husseini, S. and Suri, V. (2009) No Association of TAP1 and TAP2 Genes Polymorphism with Risk of Cervical Cancer in North Indian Population. Journal of Assisted Reproduction and Genetics, 26, 173-178. https://doi.org/10.1007/s10815-009-9301-2

[11] McLaughlin Drubin, M.E. and Munger, K. (2009) Oncogenic Activities of Human Papillomaviruses. Virus Research, 143, 195-208. https://doi.org/10.1016/j.virusres.2009.06.008

[12] Sambrook, J. and Russell, D.W. (2006) Purification of Nucleic Acids by Extraction with Phenol: Chloroform. Cold Spring Harbor Protocols. https://doi.org/10.1101/pdb.prot4455

[13] Powis, S.H., Tonks, S., Mockridge, I., et al. (1993) Alleles and Haplotypes of the MHC-Encoded ABC Transporters TAP1 and TAP2. Immunogenetics, 37, 373-380. https://doi.org/10.1007/BF00216802

[14] Gostout, B.S., Poland, G.A., Calhoun, E.S., et al. (2003) TAP1, TAP2 and HLA-DR2 Alleles Are Predictors of Cervical Cancer Risk. Gynecologic Oncology, 88, 326-332. https://doi.org/10.1016/S0090-8258(02)00074-4

[15] Deshpande, A., Cosette, M.W., William, C.H., et al. (2008) Variation in HLA Class I Antigen-Processing Genes and Susceptibility to Human Papillomavirus Type 16-Associated Cervical Cancer. The Journal of Infectious Diseases, 197, 371-381. https://doi.org/10.1086/524300

[16] Yang, T., McNally, B.A., Ferrone, S., Liu, Y. and Zheng, P. (2003) A Single-Nucleotide Deletion Leads to Rapid Degradation of TAP-1 MRNA in a Melanoma Cell Line. The Journal of Biological Chemistry, 278, 15291-15296. https://doi.org/10.1074/jbc.M300954200

[17] Vermeulen, C.F., Jordanova, E.S., Terhaar, N.T., et al. (2007) Expression and Genetic Analysis of Transporter Associated with Antigen Processing in Cervical Carcinoma. Gynecologic Oncology, 105, 593-599. https://doi.org/10.1016/j.ygyno.2007.02.016

[18] Einstein, M.H., Leanza, S., Chiu, L.G., et al. (2009) Genetic Variants in TAP Are Associated with High-Grade Cervical Neoplasia. Clinical Cancer Research, 15, 1019-1023. https://doi.org/10.1158/1078-0432.CCR-08-1207

[19] Liu, Q., Hao, C., Su, P. and Shi, J. (2009) Down-Regulation of HLA Class I Antigen-Processing Machinery Components in Esophageal Squamous Cell Carcinomas: Association with Disease Progression. Scandinavian Journal of Gastroenterology, 44, 960-969. https://doi.org/10.1080/00365520902998679

[20] Camilla, N., Stephan, P., Jasmin, R.S., et al. (2013) Association of TAP Gene Polymorphisms and Risk of Cervical Intraepithelial Neoplasia. Disease Markers, 35, 79-84. https://doi.org/10.1155/2013/368732 